\title{
camminatin \\ foxm1 Modulates Cell Non-Autonomous Response in Zebrafish Skeletal Muscle Homeostasis
}

\author{
Fábio J. Ferreira ${ }^{1,2,3,4,+(\mathbb{D} \text {, Leonor Carvalho }}{ }^{1,2,5,+(\mathbb{D}}$, Elsa Logarinho $1,3, * \mathbb{D}$ and José Bessa ${ }^{1,2, *}$ \\ 1 i3S-Instituto de Investigação e Inovação em Saúde, Universidade do Porto, 4200-135 Porto, Portugal; \\ fabio.ferreira@i3s.up.pt (F.J.F.); leonor.carvalho411@gmail.com (L.C.) \\ 2 Vertebrate Development and Regeneration Group, IBMC-Instituto de Biologia Molecular e Celular, \\ Universidade do Porto, 4200-135 Porto, Portugal \\ 3 Aging and Aneuploidy Group, IBMC-Instituto de Biologia Molecular e Celular, Universidade do Porto, \\ 4200-135 Porto, Portugal \\ 4 Graduate Program in Areas of Basic and Applied Biology (GABBA), Instituto de Ciências Biomédicas Abel \\ Salazar (ICBAS), Universidade do Porto, 4050-313 Porto, Portugal \\ 5 Departamento de Biologia Animal, Faculdade de Ciências, Universidade de Lisboa, 1749-016 Lisboa, Portugal \\ * Correspondence: elsa.logarinho@ibmc.up.pt (E.L.); jose.bessa@ibmc.up.pt (J.B.) \\ + These authors contributed equally to this work.
}

check for updates

Citation: Ferreira, F.J.; Carvalho, L.; Logarinho, E.; Bessa, J. foxm1 Modulates Cell Non-Autonomous Response in Zebrafish Skeletal Muscle Homeostasis. Cells 2021, 10, 1241. https://doi.org/10.3390/ cells10051241

Academic Editor: Sophie Thomas

Received: 27 February 2021

Accepted: 11 May 2021

Published: 18 May 2021

Publisher's Note: MDPI stays neutral with regard to jurisdictional claims in published maps and institutional affiliations.

Copyright: (c) 2021 by the authors. Licensee MDPI, Basel, Switzerland. This article is an open access article distributed under the terms and conditions of the Creative Commons Attribution (CC BY) license (https:// creativecommons.org/licenses/by/ $4.0 /)$.

\begin{abstract}
Recent data have shown that this transcription factor also modulates gene networks associated with other cellular mechanisms, suggesting non-proliferative functions that remain largely unexplored. In this study, we used CRISPR/Cas9 to disrupt foxm 1 in the zebrafish terminally differentiated fast-twitching muscle cells. foxm 1 genomic disruption increased myofiber death and clearance. Interestingly, this contributed to non-autonomous satellite cell activation and proliferation. Moreover, we observed that Cas9 expression alone was strongly deleterious to muscle cells. Our report shows that foxm1 modulates a muscle non-autonomous response to myofiber death and highlights underreported toxicity to high expression of Cas9 in vivo.
\end{abstract}

Keywords: zebrafish; foxm1; CRISPR/Cas9; skeletal muscle; satellite cells

\section{Introduction}

FOXM1 is a transcription factor considered a master regulator of the cell cycle since it promotes expression of the late cell cycle gene cluster [1-3]. Mammalian FOXM1 expression is increased in proliferative cells and is commonly found in processes involving cell division, such as embryogenesis, tissue repair and cancer [4-7]. Null mice for Foxm1 exhibit abnormalities in multiple organs concomitant with embryonic lethality [8-10]. It has been reported that while cardiomyocytes and hepatoblasts fail to complete mitosis, other cell types exhibit no visible change in proliferation rate in Foxm1 knockout mouse embryos, which suggests cell-specific functions [5]. Knockdown of foxm1 with high doses of morpholino is lethal in zebrafish embryos [11], while the cell cycle role of foxm1 in zebrafish tissue regeneration has also been particularly explored [12,13]. Mammalian and zebrafish FoxM1 homologues share the main features of protein structure and active domains [14], namely the N-terminal negative regulatory domain (NRD), which is responsible for autoinhibitory activity $[15,16]$, the DNA binding domain (DBD) and the C-terminal transactivation domain (TAD), which contains several post-translational modification sites and recruits the transcriptional machinery to target regulatory elements $[17,18]$. Loss of the C-terminal domain of FoxM1 results in downregulation of its target genes [19].

Recent data have shown that FOXM1 also regulates genes involved in many biological processes beyond cell cycle, such as DNA damage repair and cytokine production, namely in response to aging-associated cell senescence $[3,20]$. FOXM1 also appears to be 
required for mitochondrial homeostasis [21] and proper cell differentiation [5]. These results suggest that FOXM1 might have a role beyond its canonical function in proliferative cells, although its role in non-proliferative tissues has not yet been extensively explored.

Degenerative loss of skeletal muscle homeostasis with age occurs in parallel with organismal decrease of FOXM1 expression in humans [3], leading to the question of whether the former may be, in part, consequence of the latter. Crucially, high conservation of muscle gene networks and structure between mammals and zebrafish have been described [22,23]. In zebrafish, fast-twitching fibers become functional around $24 \mathrm{~h}$ post fertilization (hpf), when they can be found in the deep portion of the myotome and the compartmentalization of the zebrafish somites is complete [24,25]. From then on, secondary myogenesis supports the indeterminate growth of zebrafish through a balance between self-renewal of the resident stem cells, the Pax7-positive satellite cells, and cell differentiation [26,27]. Muscle grows through the combined increase in fiber size, resulting from fusion of myogenic progenitors to the fibers, and number, by satellite cells differentiation into new myofibers [25]. Zebrafish muscle has been previously used as a model to study muscle disease [28-30] and response to injury [31,32]. Upon injury, quiescent satellite cells in the myotome are activated and divide asymmetrically, resulting in renewal of the stem cell niche and the generation of new muscle fibers [27]. Mouse satellite cells express Foxm1, which contributes to proliferation and survival of these stem cells and proper muscle regeneration upon injury $[33,34]$. However, the high levels of Foxm 1 expression in satellite cells decrease substantially, albeit not totally, upon differentiation into myofibers [33]. Similarly, mouse myofibers express very low levels of Foxm1 [35]. Yet, it remains unknown whether foxm1 is required for proper cell function in zebrafish myofibers.

CRISPR/Cas9 technology has been used to study gene function and disease in zebrafish [36]. CRISPR/Cas9-mediated genome editing relies, in part, on the error-prone non-homologous DNA end joining (NHEJ) mechanism to repair DNA double-strand breaks (DSBs), which results in small de novo insertions and deletions (indels) [37]. Indels can then result in frameshift and non-sense mutations, with the potential to knockout gene expression either transiently, in injected F0 animals (crispants), or stably, in F1 and F2 animals $[36,38,39]$. More recent applications of CRISPR/Cas9 in zebrafish have shown that using tissue-specific expression of Cas9, it is possible to target genes in a tissue-specific manner [40]. Notwithstanding the revolutionary usefulness of CRISPR/Cas9 technology in biomedical research, recent studies have highlighted potential issues with high levels of DSBs induced by Cas9 [41,42].

In this study, we explored the role of foxm 1 in non-proliferating differentiated cells to better dissect its function beyond cell cycle progression, using zebrafish. Advantages of this animal model stand from the high number of embryos generated in each crossing, which are amenable to genetic manipulation by injection in one-cell stage, are fully transparent and develop rapidly ex utero. Our initial attempts to generate foxm 1 mutants suggest early embryonic lethality. To bypass this problem, and in order to understand the function of foxm 1 in post-mitotic cells, we used the zebrafish embryo fast-twitch muscle fibers as a model since they become functional around $24 \mathrm{hpf}$, can be promptly genetically manipulated and are easily trackable in vivo. Driving tissue-specific expression of Cas9 in fast-twitch muscle fibers to target foxm1, we found that overexpression of Cas9 alone in these myofibers induces apoptosis and cell number decline. In this context, upon foxm 1 loss-of-function in fast-twitch muscle fibers, we found that foxm 1 contributes to cell communication and non-autonomous satellite cell activation in response to Cas9-induced cell injuries. These findings support previous data suggesting FoxM1 as a regulator of DNA damage, cytokine secretion and cell communication. Our results also highlight the impact of exogenous Cas9 overexpression in cell viability, raising concerns about cell competition and tissue repair mechanisms that may hinder in vivo CRISPR/Cas9-mediated mutagenesis approaches. 


\section{Materials and Methods}

\subsection{Zebrafish Maintenance}

Adult wild-type Tuebingen (TU) zebrafish (Danio rerio) were maintained in a recirculating system under conditions approved by the i3S Animal Welfare and Ethics Committee and the Portuguese National Authority for Animal Health (DGAV). Zebrafish embryos and larvae were reared in incubators at $28^{\circ} \mathrm{C}$ during experiments or until approximately 7 days post fertilization (dpf), being then transferred to a recirculating system.

\subsection{Production of $s g R N A$ and Cas9 $m R N A$}

Nine sgRNA spacer sequences targeting foxm1 coding sequence were selected on Benchling (2018) [43] based on metrics from Doench and colleagues [44] and Hsu and colleagues [45]. Pairs of oligonucleotides where ordered (Sigma-Aldrich, Darmstadt, Germany) and annealed, followed by cloning in the BsaI-digested vector pDR274 (Addgene \#42250), as described [46]. sgRNAs were transcribed using the T7 RNA polymerase (Thermo Scientific, Vilnius, Lithuania) and the HindIII-digested sgRNA expression vector as template. The Cas9 mRNA was transcribed using the SP6 RNA polymerase (Thermo Scientific, Vilnius, Lithuania) and the NotI-digested pCS2-nCas9n (Addgene \#47929) as a template, and G(5')ppp $\left(5^{\prime}\right) \mathrm{G}$ RNA Cap Structure Analog (New England Biolabs, Ipswich, MA, USA). The transcribed RNAs were purified using a Sephadex column, followed by the phenol-chloroform extraction [47], prior to injection. sgRNA sequences can be found in the Table S1.

\subsection{Microinjection in Zebrafish Embryos}

sgRNA and Cas9-encoding mRNA were coinjected into the cell of one-cell stage zebrafish embryos. Each embryo was injected with approximately $5 \mathrm{~nL}$ of a mixture containing $150 \mathrm{ng} / \mu \mathrm{L}$ of sgRNA, $200 \mathrm{ng} / \mu \mathrm{L}$ of Cas $9 \mathrm{mRNA}$ and 10\% of phenol-red. Embryos were placed in Petri dishes with E3 medium supplemented with N-phenylthiourea, in batches of 50 embryos per plate, and reared at $28^{\circ} \mathrm{C}$.

\subsection{Detection of Mutations}

At about $24 \mathrm{hpf}$, genomic DNA was extracted from 3 pools of 8 embryos and the targeted genomic locus was amplified with the primers presented in the Table S2. The product was then denatured and reannealed to promote the formation of heteroduplexes. The presence of heteroduplexes was then assessed with an $8 \%$ polyacrylamide gel electrophoresis (PAGE). Selected bands were cut, reamplified and sent for Sanger sequencing in i3S Genomics Scientific Platform. Sequences from at least 3 different embryo batches were analyzed with TIDE [48]. Graphs with data derived from TIDE report the percentage of indels statistically significant $(p$ value $<0.05$ ). Percentages are based on the analysis of a 20-nucleotides window centered in the Cas9 cutting site. Cell type-specific CRISPR/Cas9mediated targeting of foxm1 using mylfpa:Cas9-T2A-GFP;U68.2 (see Section 2.9 of Materials and Methods) was analyzed with DNA extracted from $2 \mathrm{dpf}$ single embryos and DNA extracted from FACS-sorted GFP-positive cells from $2 \mathrm{dpf}$ embryos.

\subsection{Identification of Founders and Stable Mutant Lines}

Animals injected with sgRNA were reared until 3-month-old, at which point they were outcrossed. Genomic DNA was extracted from 3 pools of 8 embryos and processed as described above. Animals transmitting mutations in the targeted region of foxm1 (F0) were considered founders and their offspring (F1) was reared until 3-month-old. These F1 animals where then genotyped for the mutation and used to initiate stable mutant lines, with well-characterized mutations.

\subsection{Fluorescence-Activated Cell Sorting (FACS)}

Groups of 400 DsRed-positive 3 dpf embryos were selected and dechorionated. After washing with $1 \times$ PBS, embryos were digested at $32{ }^{\circ} \mathrm{C}$ with $0.125 \mathrm{mg} / \mathrm{mL}$ collagenase 
II in HBSS $\left(\mathrm{Ca}^{2+} \mathrm{Mg}^{2+}, 1 \mathrm{mM} \mathrm{CaCl}\right)$ under $800 \mathrm{rpm}$ shaking for $30 \mathrm{~min}$ and mechanical dissociation every $5 \mathrm{~min}$ using a micropipette with low adhesion tips. The cell mixture was centrifuged for $10 \mathrm{~min}$ at $500 \times g$ at $4{ }^{\circ} \mathrm{C}$ and the pellet washed with $1 \times$ PBS. The cells were then resuspended in sorting buffer ( $1 \times$ PBS, $0.5 \%$ BSA, 0.5 M EDTA, 1 M HEPES) filtered with a $40 \mu \mathrm{m}$ mesh cell strainer and kept on ice until sorting. Cell sorting was performed in a BD FACSAria II flow cytometer (BD Biosciences, San Diego, CA, USA) using the yellow/green laser $(561 \mathrm{~nm})$. Cells were gated by forward scatter area (FSC-A) vs. side scatter area (SSA-A) and FSC-A vs. FSC-height (FCS-H) plots to exclude dead cells and doublets/clumps, respectively. The gates were established based on the autofluorescence of WT embryo cells. Cells were selected based on the DsRed expression. The collected cell suspension was centrifuged at $300 \times g$ for $10 \mathrm{~min}$ and the pellet was resuspended in TRIzol (Ambion, Life Technologies, Carlsbad, CA, USA), vortexed and stored at $-20^{\circ} \mathrm{C}$. The same procedure was applied to groups of 50-100 GFP-positive $2 \mathrm{dpf}$ embryos injected with mylfpa:Cas9-T2A-GFP;U6:8.2, but the blue laser (488 nm) was used and the GFP-positive sorted cells were collected to $1 \times$ PBS and further used for genotyping.

\subsection{Tissue-Specific CRISPR/Cas9}

The MultiSite Gateway technology was used to create vectors driving expression of Cas9 specifically in muscle cells. Briefly, a $1999 \mathrm{bp}$ sequence of the mylfpa promoter cloned in the p5E-MCS (Addgene \#26029), kindly provided by the David Langenau's group, the pME-Cas9-T2A-GFP (Addgene \#63155) and the p3E-polyA (Tol2kit v1.2 \#302) were cloned in the pDestTol2pA2-U6:sgRNA (Addgene \#63157) using the LR Clonase II Plus enzyme (Invitrogen, Bleiswijk, Netherlands). The functional sgRNAs targeting foxm 1 was then cloned in the BseRI-digested final vector (Addgene \#63157). A version of the final vector without any introduced sgRNA was used as a negative control. To follow mylfpa-positive cells in the absence of Cas9 expression, the pME-mCherry (Tol2kit v1.2 \#386) was used as a middle entry vector instead of pME-Cas9-T2A-GFP and no sgRNA was inserted in the final vector.

\subsection{Tol2 Transposase Synthesis}

The Tol2 transposase mRNA was transcribed using the SP6 RNA polymerase (Thermo Scientific, Vilnius, Lithuania) and the NotI-digested pCS2FA-transposase vector (Tol2kit v1.2 \#396), and including G(5')ppp(5')G RNA Cap Structure Analog (New England Biolabs, Ipswich, MA, USA), as described [47]. The transcribed RNAs were purified as described above.

\subsection{Tissue-Specific Mutagenesis Assay}

One-cell stage embryos were injected with approximately $5 \mathrm{~nL}$ of a mixture containing $25 \mathrm{ng} / \mu \mathrm{L}$ of Tol2 transposase mRNA, $50 \mathrm{ng} / \mu \mathrm{L}$ of the transgenesis-control vector and $150 \mathrm{ng} / \mu \mathrm{L}$ of either sgRNA containing vector or the empty vector. At 1, 2, 3 and $5 \mathrm{dpf}$ embryos were screened under a fluorescence stereomicroscope (Leica M205, Leica Microsystems, Wetzlar, Germany) and photographed (Hamamatsu ORCA-Flash4.0 LT camera, Hamamatsu Photonics, Hamamatsu, Japan). GFP-positive and mCherry-positive cells were quantified at each timepoint, using Fiji-ImageJ [49]. The total number of cells in each embryo was normalized to the average number of cells in embryos from the control sample.

\subsection{RNA Extraction and Reverse Transcription}

RNA was extracted from FACS-sorted cells and 3 dpf embryos with TRIzol (Ambion, Life Technologies, Carlsbad, CA, USA), following the manufacturer's instructions. RNA was treated with DNase I (Thermo Scientific, Vilnius, Lithuania). Samples were quantified in NanoDrop 1000 and stored at $-80^{\circ} \mathrm{C}$. RNA was retrotranscribed into cDNA using the SuperScript II Reverse Transcriptase (Invitrogen, Carlsbad, CA, USA), according to the manufacturer's instructions. 


\subsection{Real Time Quantitative PCR (RT-qPCR)}

RT-qPCR was performed using iTaq Universal SYBR Green Supermix (Bio-Rad, Hercules, CA, USA) in a thermocycler (CFX96 Touch Real-Time PCR Detection System, Bio-Rad, Hercules, CA, USA) with the following program: $95^{\circ} \mathrm{C}$ for $3 \mathrm{~min}$ followed by 39 cycles of $95{ }^{\circ} \mathrm{C}$ for $30 \mathrm{~s}, 56{ }^{\circ} \mathrm{C}$ for $30 \mathrm{~s}$ and $72{ }^{\circ} \mathrm{C}$ for $30 \mathrm{~s}$. Non-reverse transcribed and blank controls were included. Six biological replicates with three technical replicates were used per target gene. Expression was normalized with the $b 2 m$ and eef1a1 housekeeping genes, and different biological replicates were normalized to the mean expression of the control (DsRed-negative cells). Primers used in RT-qPCR are presented in Table S3.

\subsection{Cleaved Caspase-3 Immunostaining and Quantification}

Cleaved caspase-3 immunostaining was performed as previously described [50], with minor adjustments. Briefly, embryos injected with mylfpa:mCherry, mylfpa:Cas9-T2A-GFP or mylfpa:Cas9-T2A-GFP;U6:8.2, and non-injected embryos, were sacrificed with MS222 overdose at $2 \mathrm{dpf}$ and fixed in $4 \%$ paraformaldehyde (Electron Microscopy Sciences, Hatfield, PA, USA) in phosphate-buffered saline $(1 \times$ PBS $)$ overnight at $4{ }^{\circ} \mathrm{C}$. Embryos were permeabilized with $100 \%$ methanol at $-20{ }^{\circ} \mathrm{C}$ for $2 \mathrm{~h}$ to $24 \mathrm{~h}$. After rehydration in $75 \%, 50 \%$ and $25 \%$ methanol in PDT ( $1 \times$ PBS, $0.1 \%$ Tween-20, $0.3 \%$ Triton- $X, 1 \%$ DMSO), embryos were washed twice in PDT for $30 \mathrm{~min}$ at RT and incubated in blocking buffer (1 $\times$ PDT, 10\% heat-inactivated fetal bovine serum, 2\% bovine serum albumin) for $1 \mathrm{~h}$ at RT. Embryos were then incubated overnight with an anti-cleaved caspase-3 antibody (1:200, Cat. PC679, Calbiochem, Merck, Darmstadt, Germany) diluted in blocking buffer. After washes in PDT, embryos were incubated with anti-rabbit Alexa 488 (1:800, Invitrogen, Eugene, OR, USA) or anti-rabbit Alexa 568 (1:800, Invitrogen, Eugene, OR, USA) diluted in blocking buffer for $4 \mathrm{~h}$ at RT. Embryos were washed in PDT as above and stored at $4{ }^{\circ} \mathrm{C}$ in $50 \%$ glycerol in $1 \times$ PBS. Microscopy slides were prepared using $50 \%$ glycerol in $1 \times$ PBS. Z-stacks of the embryo's trucks were obtained with a fluorescence stereomicroscope (Leica M205, Leica Microsystems, Wetzlar, Germany) and camera (Hamamatsu ORCA-Flash4.0 LT, Hamamatsu Photonics, Hamamatsu, Japan). Cleaved caspase-3-positive myofibers cells were quantified using Fiji-ImageJ [49].

\subsection{Pax7 Immunostaining and Quantification}

Embryos injected with mylfpa:Cas9-T2A-GFP or mylfpa:Cas9-T2A-GFP;U6:8.2 were sacrificed with MS-222 overdose and fixed in $4 \%$ paraformaldehyde (Electron Microscopy Sciences, USA) in phosphate-buffered saline $\left(1 \times\right.$ PBS) overnight at $4{ }^{\circ} \mathrm{C}$, rinsed in $0.1 \%$ PBS-T ( $0.1 \%$ Triton X-100 in $1 \times$ PBS), permeabilized $1 \mathrm{~h}$ with $0.5 \%$ PBS-T and blocked $1 \mathrm{~h}$ with blocking buffer ( $2 \%$ normal goat serum, $2 \mathrm{mg} / \mathrm{mL}$ BSA, $0.1 \%$ Tween 20 in PBS). Embryos were incubated overnight with an anti-Pax7 antibody [51] (1:50, monoclonal, Developmental Studies Hybridoma Bank, Iowa City, IA, USA) diluted in blocking buffer. Embryos were then incubated with anti-mouse Alexa 568 (1:800, Invitrogen, Eugene, OR, USA) and DAPI (1:1000, Invitrogen, Eugene, OR, USA), diluted in blocking buffer. Embryos were rinsed as above and stored in $50 \%$ glycerol in $1 \times$ PBS. Microscopy slides were prepared using $50 \%$ glycerol in $1 \times$ PBS. Images were acquired with a laser point scanning confocal microscope (Leica TCS SP5, Leica Microsystems, Wetzlar, Germany). Positive satellite cells in the central myotome and the vertical and horizontal myosepta where quantified, while xanthophores, pigment cells in the surface of somites, with higher intensity staining and bean-shaped nuclei were excluded [52].

\subsection{Statistical Analysis}

The statistical analysis was performed using Microsoft Office Excel and GraphPad Prism 8 software. Significant differences $(p$ value $<0.05)$ from 6 independent experiments in the qPCR assay and 13 embryos in the Pax7 immunostaining assay were determined by a Student's $t$-test. Significant differences $(p$ value $<0.05$ ) between at least 34 embryos per conditions in the tissue-specific mutagenesis assay were calculated with a one-way 
ANOVA with Bonferroni correction for multiple comparisons. Significant differences ( $p$ value $<0.05$ ) between samples with $\geq 42$ embryos per condition in the cleaved caspase- 3 immunostaining assay were determined by the Fisher's exact test using the discrete values.

\section{Results and Discussion}

\section{1. foxm1 Loss-of-Function Is Deleterious during Zebrafish Embryogenesis}

CRISPR/Cas9 technology can be used to produce frameshift-inducing indels in zebrafish embryos [53]. Frameshift mutations can lead to mRNAs with premature termination codons (PTCs) or mRNAs coding aberrant, non-functional proteins. PTCs often result in nonsense-mediated decay (NMD) of the target transcript, with consequential genetic knockdown $[54,55]$. In zebrafish, the NMD effectors are transmitted maternally and expressed ubiquitously from early embryogenesis [56]. With that in mind, we designed six sgRNAs targeting the exon 2 of foxm1 (sgRNAs 2.1-2.6), downstream the start codon, to generate a PTC that would lead to foxm 1 knockdown in zebrafish (Figure 1A). We also designed three sgRNAs targeting exon 8 (sgRNAs 8.1-8.3), aiming to disrupt the sequence coding the protein transactivation domain (TAD) (Figure 1A). Since all possible premature out-of-frame stop codons created by targeting exon 8 of foxm 1 are downstream the last exon junction, NMD is unlikely to function efficiently [56,57], meaning frameshift mutations may ultimately result in an unstable mRNA or protein that lacks its C-terminal TAD. In fact, in humans an alternatively spliced FOXM1 transcript generates a frameshift and a PTC in the C-terminal domain that results in a truncated protein with dominant negative activity [19]. Moreover, indels that keep the correct transcription reading frame may still affect protein function by affecting post-translational modification motifs of foxm 1 in the targeted region $[18,58,59]$. In each experiment, we confirmed the efficiency of CRISPR/Cas9 by knocking down expression of eGFP in a stable line previously generated in the lab (Tg(elavl3:GFP)), using the same Cas9 mRNA batch (Figure S1A-C). A PAGE-based assay to detect heteroduplexes [60] revealed the presence of indels only in the target site of sgRNA 8.2 out of the nine tested sgRNAs (Figure S1D-G). Our results contrast with previous reports showing a higher mutagenesis efficiency for different sgRNAs in zebrafish [46]. These results suggest that most indels in the zebrafish foxm 1 sequence are strongly deleterious leading to a selection of non-mutated cells. Additionally, these data suggest that loss of foxm1 is not transcriptionally compensated by other genes [61], such as other fox genes, likely as result of foxm 1 sequence divergence in relation to other fox genes $[62,63]$. For the scope of this work, we decided to proceed using the validated sgRNA 8.2.
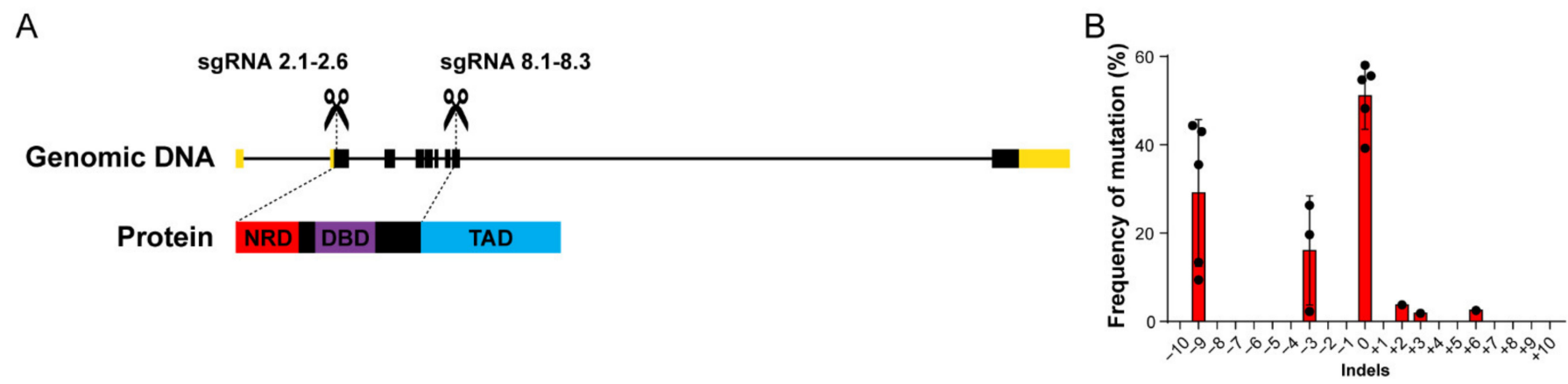

Figure 1. foxm1 CRISPR/Cas9-mediated disruption results in in-frame deletions. (A) The genomic sequence of foxm1 highlighting the $5^{\prime}$ and $3^{\prime}$ UTRs (yellow boxes), exons (black boxes) and regions targeted with CRISPR/Cas9. This strategy targets the NRD and the TAD domains. (B) Statistically significant deletions ( $p$ value $<0.05$ ) detected at 24 hpf in batches of 8 embryos injected with sgRNA 8.2. Frequency reflects abundancy of WT and mutant alleles. $n=5$.

To understand the nature of mutations generated by sgRNA 8.2., we used TIDE [48], an online tool that identifies and determines the frequency of CRISPR/Cas9-mediated mutations. We found that the most frequent indels generated upon injection of sgRNA 8.2 were deletions of three and nine nucleotides, as detected in $24 \mathrm{hpf}$ F0 embryos (Figure 1B). 
Embryos injected with sgRNA 8.2 were reared to adulthood and outcrossed. From 14 outcrossed F0 fish, 9 fish $(64 \%)$ transmitted a mutation in exon 8 of foxm 1 to their offspring (Table 1). We sequenced the target region of these F1 embryos, and we were able to verify the existence of three different mutations, corresponding to the deletion of 3,9 or 12 nucleotides (Table 1). Strikingly, in all analyzed F1 animals, no frameshift mutations were detected. Although recent studies have shown that Cas9-induced DNA breaks and repair outcomes are non-random [64,65], we expect that about two in three indels would result in a frameshift mutation, as an even distribution of frames resulting from indels was expected [46,53]. We analyzed the results reported by Hwang and colleagues [46] in nine loci, and we found that $72.7 \%$ of the reported mutant sequences corresponded to frameshift-inducing indels. Applying a Fisher's exact test, we found that the frequency of frameshift mutations observed in the 14 mutations described in Table 1 is statistically different from what has been previously described ( 80 frameshift mutations out of 110 , vs. 0 frameshift mutations out of $14 ; p<0.0001$ ). Therefore, the total absence of frameshiftinducing indels further suggests that frameshifts in the foxm 1 gene targeted regions are strongly deleterious to all somatic and germline cells, even in heterozygosity. This strong effect could be associated with a dominant negative effect of the resulting protein, similarly to a known truncated form of the human FOXM1 [19]. To bypass the detrimental effect of foxm 1 targeting with sgRNA 8.2 during embryogenesis and assess the effects of foxm 1 disturbance in non-proliferative cells we next focused on a conditional cell type-specific loss-of-function of foxm1.

Table 1. Genomic deletions driven by sgRNA 8.2, protein translation and respective frequencies of germline transmission detected in F1 embryos.

\begin{tabular}{|c|c|c|c|}
\hline Genotype & DNA Sequence & aa Sequence & Frequency $(N)$ \\
\hline Wild type & ... AAGATGAAGCCTCTACTGCCTCGGACTGAC ... & ... KMKPLLPRTD . . . & $36 \%(5)$ \\
\hline 3 nts deletion & ... AAGATGAAGCCTCTACTGCCTCGGACTGAC ... & ... KMKPLLPRTD ... & $7 \%(1)$ \\
\hline 9 nts deletion & ... AAGATGAAGCCTCTACTGCCTCGGACTGAC ... & ... KMKPLLEPRTD ... & $43 \%(6)$ \\
\hline 12 nts deletion & ... AAGATGAAGCCTCTACTGCCTCGGACTGAC ... & 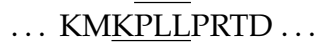 & $14 \%(2)$ \\
\hline
\end{tabular}

nts, nucleotides; aa, amino acid; N, number of embryos.

\section{2. foxm1 Is Expressed in Skeletal Muscle Cells}

Considering the reported roles of foxm 1 in biological processes beyond the cell cycle $[3,20,21]$, we studied the phenotype generated by the loss of foxm 1 in skeletal muscle cells. Although skeletal muscle cells keep their cell cycle machinery intact [66], the study of skeletal myofibers in zebrafish somites, which are fully differentiated and do not proliferate in response to injury [27], allowed us to investigate for potential roles of foxm 1 beyond cell cycle regulation. We started by assessing whether foxm 1 was indeed expressed in muscle fibers. We used a previously established line that expresses DsRed in the fast-twitching muscle fibers [67] and measured foxm 1 expression in FACS-sorted DsRed-positive cells, in $3 \mathrm{dpf}$ embryos. When compared to the DsRed-negative embryo cells, that include all kind of proliferative and differentiated cells except fast-twitching muscle cells, skeletal muscle cells expressed foxm 1 at lower but detectable levels (Figure 2A). Previous studies analyzing young adult mice by RNA-seq revealed very low but detectable levels of Foxm 1 in single myofibers [35], consistent with our results. Similarly, other studies have shown that purified Pax7-negative mouse myofibers also expressed Foxm 1 at low levels [33]. Finally, transcriptomic and proteomic data from the Human Protein Atlas [68] further show that FOXM1 is very mildly expressed in human skeletal muscle. These data show that three phylogenetically distant vertebrates, zebrafish, mouse and human, express foxm 1 in muscle fibers, suggesting a conserved role, likely in cell homeostasis. 

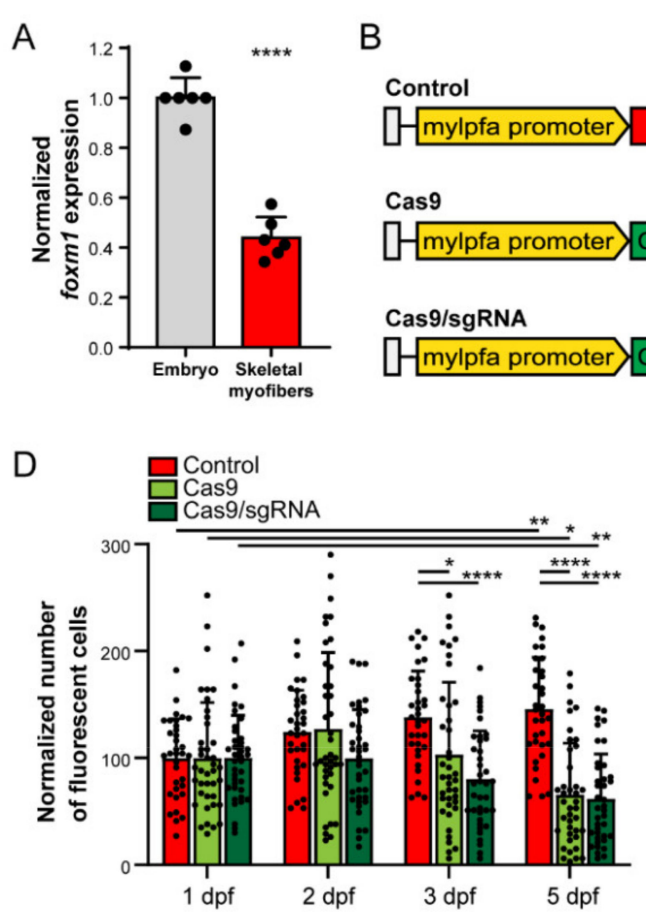

$\mathrm{F}$
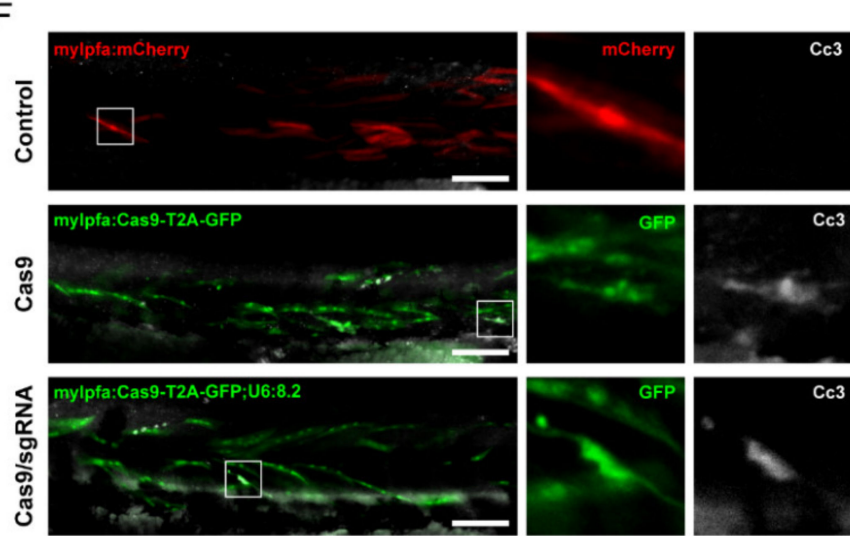

$\mathrm{E}$
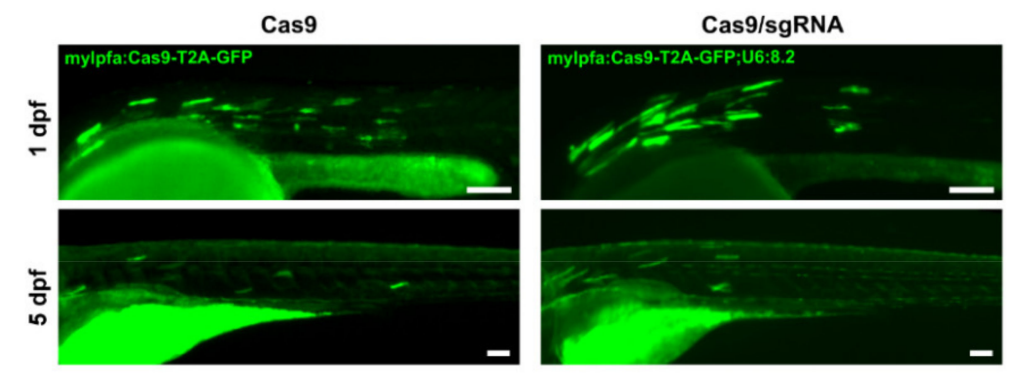

G

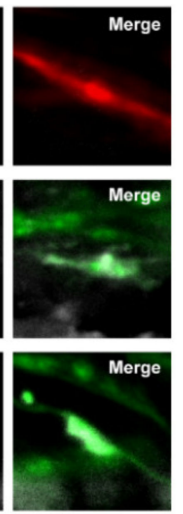

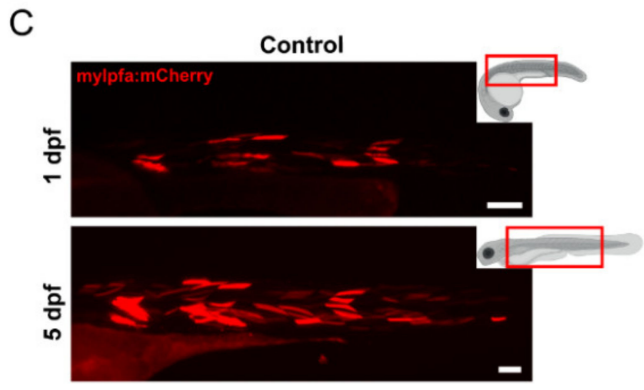

Figure 2. Skeletal muscle cell-specific targeting of foxm 1 with CRISPR/Cas9 is detrimental. (A) Expression of foxm 1 in whole zebrafish embryo (except skeletal myofibers) and FACS-sorted skeletal myofibers at 3 dpf. Values are mean \pm SD from $n=6 .{ }^{* * *}=p<0.0001$ by Student's $t$-test. (B) Representation of the Tol 2 cassettes used for transgenesis in this study. White bar represents the Tol2 recombination sites, pA refers to the poly-A sequence and U6 refers to the ubiquitous U6 promoter. (C) Embryo injected with mylpfa:mCherry, at 1 (top) and $5 \mathrm{dpf}$ (bottom). Fluorescence microscopy images correspond to the embryo areas indicated by red boxes on the right. (D) Quantification of mCherry-positive (Control) or the GFP-positive (Cas9 and Cas9/sgRNA) cells at 1, 2, 3 and $5 \mathrm{dpf}$. Values are mean \pm SD from $n \geq 34$ embryos, ${ }^{*}=p<0.05$, ${ }^{* *}=p<0.01,{ }^{* * * *}=p<0.0001$ by one-way ANOVA with Bonferroni correction for multiple comparisons. (E) Embryo injected with mylfpa:Cas9-T2A-GFP (Cas9) and mylfpa:Cas9-T2A-GFP;U6:8.2 (Cas9/sgRNA), at 1 (top) and 5 dpf (bottom). (F) 2 dpf embryos injected with mylpfa:mCherry (Control), mylfpa:Cas9-T2A-GFP (Cas9) or mylfpa:Cas9-T2A-GFP;U6:8.2 (Cas9/sgRNA) stained with anti-cleaved caspase-3 (Cc3) antibody. (G) Quantification of 2 dpf embryos with Cc3-negative (Cc3-, gray) and Cc3-positive (Cc3+, red) myofibers from $n \geq 42$ embryos per condition. ${ }^{* * *} p<0.0001$ by Fisher's exact test using the discrete number of embryos per condition, comparison with control embryos. Scale bar: $100 \mu \mathrm{m}$.

\section{3. foxm1 Loss-of-Function and Strong Cas9 Expression Impair Muscle Cell Viability}

To track individual muscle fibers in time, we built a Tol2 transposon carrying a cassette with the mylpfa promoter driving expression of mCherry (mylpfa:mCherry, Figure 2B,C). The myosin light chain, phosphorylatable, fast skeletal muscle a (mylpfa) gene is specific to fast-twitch cells, and its cell-specific promoter has been frequently used to create ze- 
brafish transgenic reporter lines and study fast-twitching muscle cells in development [69], myogenesis [70] and regeneration [71]. The gene is active in somitic muscle as well as eye, jaw, gill and fin muscles [69]. We quantified the mCherry-positive cells in the somitic skeletal muscle of individual embryos at 1, 2, 3 and $5 \mathrm{dpf}$ and observed that the number of mCherry-positive muscle fibers increased significantly between 1 and $5 \mathrm{dpf}$ (Figure 2C,D and Figure S2A). This result translates the known formation of new myofibers from satellite cells and progenitors throughout the continuous growth of skeletal muscle in zebrafish [40].

Next, we performed a conditional loss-of-function of foxm1, targeting specifically fast-twitching muscle fibers. We used a previously described modular cell type-specific CRISPR/Cas9-mediated mutagenesis system [40]. Using this system, we have generated a Tol2 transposable element containing a cassette with the mylpfa promoter driving expression of Cas9-T2A-GFP and the ubiquitous promoter U6 driving expression of the sgRNA 8.2 (mylfpa:Cas9-T2A-GFP;U6:8.2, Figure 2B). To account for possible Cas9 effects, we used the same cassette without sgRNA as control (mylfpa:Cas9-T2A-GFP) (Figure 2B). We injected both constructs in parallel and found that the number of GFP-positive cells decreased significantly at $3 \mathrm{dpf}$ and onwards, including upon Cas 9 expression alone (Figure 2D,E and Figure S2A). This result suggests that strong expression of Cas9 in muscle fibers is enough to induce cell toxicity and clearance. Interestingly, we observed that the co-expression of sgRNA and Cas9 reduced the number of GFP-positive cells early on at $2 \mathrm{dpf}$ and induced a highly significant decrease from $3 \mathrm{dpf}$ onwards, in comparison to Cas 9 expression alone that had a more modest initial impact and reduced the number of cells only from $3 \mathrm{dpf}$ onward (Figure 2D). To validate the cell type-specific CRISPR/Cas9-mediated mutagenesis system, we performed DNA extraction from 2dpf whole embryos injected with mylfpa:Cas9-T2AGFP;U6:8.2, and FACS-sorted GFP-positive cells derived from those embryos, and we were able to found indels in the targeted foxm 1 locus (Figure S2B,C). Thus, although Cas9 is enough to induce a decrease in cell number, the formation of indels in exon 8 of foxm 1 in muscle fibers is slightly more impactful, pointing to a foxm 1 function in differentiated non-proliferative fast-twitching muscle fibers. One possibility is the foxm 1 role in DNA damage response [20] that might counteract the cell damage induced by Cas9 overexpression. Another possibility could be the recently described foxm 1 role in the regulation of mitochondrial respiration [21], critical for muscle cell viability. Interestingly, this novel foxm 1 role in the regulation of mitochondrial functions is independent of transcriptional activity and would apply even if sgRNA 8.2 generates a C-terminal truncated isoform.

The deleterious effect of the strong, continuous expression of Cas 9 alone, driven by the potent mylpfa promoter, might be caused by accumulation of high levels of the protein, affecting proteostasis, and by random DNA nicks and DSBs in unspecific sites at a scale that cells are unable to cope with and thus senesce or die. We investigated the fate of Cas9- and Cas9/sgRNA-expressing cells by performing an immunostaining for cleaved caspase-3 (Cc3), a main effector of apoptotic cell death [72,73]. Caspase-3 is conserved in zebrafish [74] and Cc3 has been successfully detected in zebrafish embryos [50,75,76]. We injected the mylpfa:mCherry (Control), mylfpa:Cas9-T2A-GFP (Cas9) and mylfpa:Cas9T2A-GFP;U6:8.2 (Cas9/sgRNA) vectors and quantified the number of $2 \mathrm{dpf}$ embryos with Cc3-positive myofibers in each condition (Figure 2F,G). No Cc3-positive myofibers were detected in non-injected and control embryos, suggesting that the integration of the Tol2 transposon and expression of the reporter gene do not cause apoptosis. In contrast, expression of Cas9 in myofibers induces muscle cell death in a significative number of embryos. The number of Cc3-positive cells per embryos was low (mean $=1.02$ cells $/$ embryo), in agreement with Cc3-positive dying cells being efficiently cleared by the zebrafish immune system's phagocytes [77,78], and with the decreasing number of Cas9-T2A-GFP-expressing myofibers observed in time. Coexpression of sgRNA 8.2 in myofibers generated equivalent low number of Cc3-positive cells per embryo (mean $=1.03$ cells/embryo), again consistently with efficient clearance and observed reduction in GFP-positive muscle cells in time. Thus, our data suggest that mylpfa-driven Cas9 expression in myofibers is detrimental to cell homeostasis and causes apoptosis. This raises safety concerns about the use of Cas9 in 
in vivo models and to clinical applications. Interestingly, recent data suggests that Cas9 induces DNA DSBs, genomic instability, and cell cycle arrest independently of sgRNAs binding or even nuclease activity [42], and in vivo studies in mice suggest Cas9 may be neurotoxic [79].

\section{4. foxm1 in Muscle Cells Contributes to Non-Autonomous Tissue Repair}

Previous data has shown that manipulations of FOXM1 expression in human primary dermal fibroblasts affect clusters of genes associated with cell senescence and cell communication, namely through regulation of senescence-associated secretory phenotype (SASP) genes [3]. Interestingly, in recent years several studies have established the association of myokines secreted by muscle fibers with paracrine, autocrine and endocrine effects with systemic and local impact [80-82], such as muscle homeostasis and remodeling itself, namely in zebrafish $[83,84]$. We therefore asked whether foxm 1 loss-of-function in muscle cells has non-autonomous effect in tissue repair. Since a decrease in cell number and increase in apoptosis was clear upon injection of the mylfpa:Cas9-T2A-GFP;U68.2 and mylfpa:Cas9-T2A-GFP vectors, tissue regeneration is expected to occur and revert cell loss. Supporting this hypothesis, increased number of dead embryos was not observed in these two conditions, thus suggesting that active homeostatic mechanisms are likely compensating cell loss. Therefore, we further explored how the tissue was responding to the damage in myofibers. For that, we coinjected the mylpfa:mCherry cassette and the mylpfa:Cas9-T2A-Cas9 cassette with and without the sgRNA 8.2 and quantified the number of mCherry- and GFP-positive cells at 1, 2, 3 and $5 \mathrm{dpf}$ (Figure 2B, Figure 3A,B and Figure S2A). In this experiment, by counting the variation of mCherry-positive cells, we were able to assess the muscle-specific response to the damage caused by Cas 9 alone or Cas 9 and foxm 1 indels combined. We observed that the increase in the number of mCherrypositive cells was more pronounced in the coinjection conditions, supporting the idea that cell damage caused by Cas 9 toxicity induced non-autonomous cell response toward muscle fiber regeneration (Figure 3A,B). Embryos injected with the cassette containing the sgRNA 8.2 presented significantly more mCherry-positive cells than the embryos injected with the mylpfa:Cas9-T2A-GFP cassette at $5 \mathrm{dpf}$ (Figure 3A,B). Therefore, foxm 1 loss-of-function specifically in fast-twitching muscle fibers significantly increases myogenesis in response to damage, suggesting that foxm 1 is required for proper tissue homeostasis. Critically, we did not observe a significant difference in the number of GFP-positive cells between embryos injected with or without the sgRNA-containing vector (Figure 2D), neither a significant difference in the number of embryos with Cc3-positive myofibers, excluding a causal contribution of differences in cell loss for the differences in mCherry-positive cells observed between Cas 9 alone and combined with foxm 1 indels.

To further investigate the cell non-autonomous effect of foxm 1 in myogenesis, we quantified the number of Pax7-positive satellite cells in the central myotome and the vertical and horizontal myosepta in $3 \mathrm{dpf}$ embryos injected with the mylfpa:Cas9-T2A-GFP;U6:8.2 or mylpfa:Cas9-T2A-Cas9 cassettes (Figure 3C). The activation and proliferation of these muscle-resident stem cells occurs during larval and adult tissue growth and regeneration $[25,27,32,85]$. We found a significant increase in the number of Pax7-positive cells per somite in the larvae treated with the sgRNA 8.2 (Figure 3D,E). Previous data has shown an increase in the number of Pax7-positive satellite cells in response to small muscle injury, in zebrafish embryos with $3 \mathrm{dpf}[85,86]$, suggesting that our genetic manipulation of the foxm 1 locus generates a similar non-autonomous signal that also stimulates satellite cells activation and proliferation, followed by differentiation into myoblasts and formation of new myofibers. Further studies are needed to elucidate the specific signaling pathways involved in the paracrine effect being affected by foxm 1 manipulation. It is known that mammalian FoxM1 regulates expression of cytokines such as IL-6 [3,87,88], a myokine produced by muscle fibers $[89,90]$ that has been associated with satellite cell and myoblast proliferation and differentiation via the JAK-STAT pathway [90] in humans. Other growth factors and cytokines, such as leukemia inhibitory factor (LIF) [91], hepatocyte growth fac- 
tor (HGF) [92], bone morphogenetic proteins (BMPs) [93-95] and fibroblast growth factors

(FGFs) [96] have also been associated with satellite cell proliferation and differentiation.
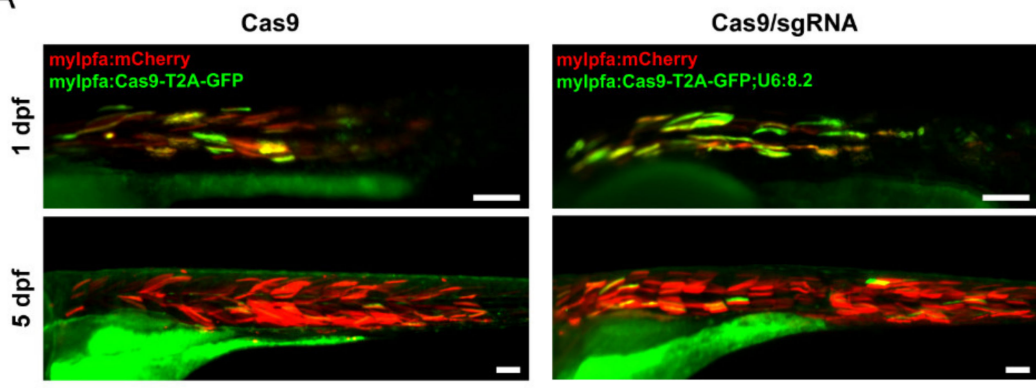

D
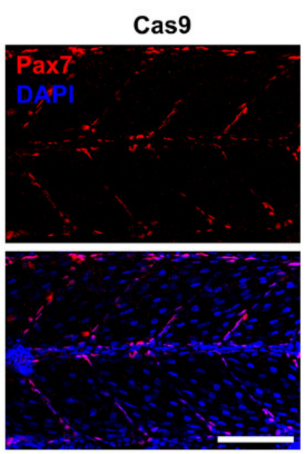

B

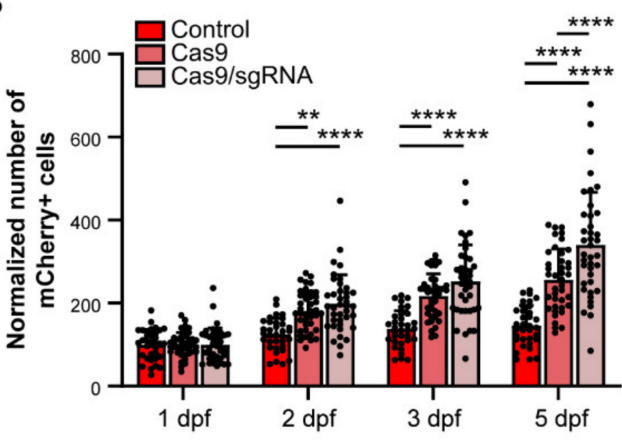

E
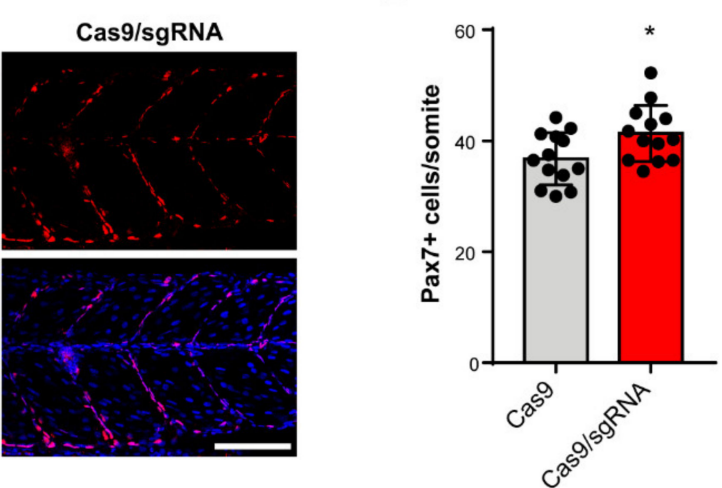

Figure 3. foxm1 in skeletal muscle cells contributes for non-autonomous signaling and tissue homeostasis. (A) mCherrypositive cells in embryos also injected with mylfpa:Cas9-T2A-GFP (Cas9) and mylfpa:Cas9-T2A-GFP;U6:8.2 (Cas9/sgRNA), at 1 and $5 \mathrm{dpf}$. (B) Quantification of mCherry-positive cells in control, Cas9 and Cas9/sgRNA embryos at 1, 2, 3 and 5 dpf. Values are mean \pm SD from $\mathrm{n} \geq 34$ embryos per condition. ${ }^{* *} p<0.01,{ }^{* * *} p<0.0001$ by one-way ANOVA with Bonferroni correction for multiple comparisons. (C) Illustration of a $3 \mathrm{dpf}$ larva and the region used for Pax7 immunostaining quantitative analysis. Red dashed lines represent the quantified cells in the central myotome and the vertical and horizontal myosepta. (D) Embryos of 3 dpf injected with mylfpa:Cas9-T2A-GFP (Cas9) or mylfpa:Cas9-T2A-GFP;U6:8.2 (Cas9/sgRNA) stained with anti-Pax7 antibody and DAPI. (E) Quantification of Pax7-positive cells per somite in 3 dpf embryos. Values are mean $\pm \mathrm{SD}$, from $n=13$ embryos per condition. ${ }^{*}=p<0.05$ by a Student's $t$-test. Scale bar: $100 \mu \mathrm{m}$.

In sum, our results suggest that normal foxm 1 expression in differentiated skeletal muscle fibers contributes to tissue homeostasis in response to cell death. Considering the beforementioned role of foxm 1 in the modulation of cytokines expression and in the inhibition of SASP, and the signaling pathways impacting satellite cells, our data supports the contribution of foxm 1 to a non-autonomous regulation of satellite cells activation and formation of new muscle fibers in response to cell injury. This regulation may prevent stem cell exhaustion and deregulation of tissue size. Although further studies on the genes being regulated by foxm 1 in myofibers and the associated mechanisms of satellite cell activation are needed, our results add evidence to the role for foxm 1 as a regulator of cell signaling genes $[3,97,98]$, controlling non-autonomous stem cell activation and proliferation in response to tissue damage.

\section{Conclusions}

Our work points to a role of foxm 1 in zebrafish development and fast-twitching muscle cell homeostasis. Using CRISPR/Cas9 technology with a single sgRNA we generated several stable mutant lines with small deletions in the transactivation domain of FoxM1. 
The lack of frameshift mutations in somatic cells and germ line transmission suggests loss of foxm 1 expression is strongly deleterious.

We also reported that expression of Cas9 by a strong, cell-specific promoter, mylpfa, leads to cell death. Moreover, Cas9-associated cell loss seems to be accelerated by CRISPR/ Cas9-mediated mutagenesis of the foxm 1 gene, supporting a cell autonomous function in muscle cells. Crucially, our results also suggest that the muscle cell-specific loss of foxm 1 contributes to satellite cell activation and proliferation, evidencing an additional cell non-autonomous role of foxm 1 required for skeletal muscle homeostasis.

Supplementary Materials: The following are available online at https://www.mdpi.com/article/10 .3390/cells10051241/s1, Figure S1: Validation of CRISPR/Cas9-mediated gene disruption methodology, detection of heteroduplexes and impact of sgRNA 8.2 in F0 embryos. Figure S2: Representative images of zebrafish embryos from the different conditions through time, at 1, 2, 3 and $5 \mathrm{dpf}$ and cell-specific impact of sgRNA 8.2 in 2 dpf myofibers. Table S1: Oligonucleotides used for targeting foxm1. Target-specific sequence in capital letters. Overhangs for insertion into expression vector in lowercase letters. Table S2: Primers used in this study. Table S3: Primers used for RT-qPCR analysis.

Author Contributions: J.B. designed and supervised the study. E.L. supervised the work and gave important inputs to the study. F.J.F. contributed to the design of the experiments and F.J.F. and L.C. performed the experiments. All authors contributed to the writing of the manuscript and for the development and discussion of the work. All authors have read and agreed to the published version of the manuscript.

Funding: This study was supported by the European Research Council (ERC) under the European Union's Horizon 2020 research and innovation program (ERC-2015-StG-680156-ZPR). FEDER (Fundo Europeu de Desenvolvimento Regional) funds through the COMPETE 2020-Operational Programme for Competitiveness and Internationalization (POCI), Portugal 2020 and by Portuguese funds through FCT (Fundação para a Ciência e a Tecnologia) in the framework of the project POCI-01-0145-FEDER-031120 (PTDC/BIA-CEL/31120/2017); and POCI-01-0145-FEDER-007274 i3S framework project co-funded by COMPETE 2020/PORTUGAL 2020 through FEDER. E.L. and J.B. are supported by FCT (J.B.: Grant CEECIND/03482/2018; E.L.: Grants CEECIND/00654/2020 and IF/00916/2014). F.J.F. (PD/BD/105745/2014) is a PhD fellow from FCT.

Institutional Review Board Statement: Handling of animals was conducted according to standard guidelines reviewed by the Animal Welfare and Ethics Review Body of i3S. The Animal Facility of the i3S is licensed by the Portuguese National Authority for Animal Health (DGAV), accredited by the Association for Assessment and Accreditation of Laboratory Animal Care International (AAALAC International, June, 2018), complies with Portuguese law (Portaria 1005/02 and Portaria 1131/97), the 2010/63/EU Directive, and follows the Federation of European Laboratory Animal Science Associations (FELASA) guidelines and recommendations concerning laboratory animal welfare.

Acknowledgments: We thank Inês Tenente and David Langenau for vectors. We also thank the Advanced Light Microscopy, member of PPBI (POCI-01-0145-FEDER-022122), the Translational Cytometry i3s Scientific Platform, Marta Duque for optimization of the zebrafish embryo dissociation protocol and João Pedro Amorim's, Joana Marques' and Isabel Guedes' contribution for the maintenance of the zebrafish lines.

Conflicts of Interest: The authors report no conflict of interest.

\section{References}

1. Laoukili, J.; Kooistra, M.R.H.; Brás, A.; Kauw, J.; Kerkhoven, R.M.; Morrison, A.; Clevers, H.; Medema, R.H. FoxM1 Is Required for Execution of the Mitotic Programme and Chromosome Stability. Nat. Cell Biol. 2005, 7, 126-136. [CrossRef]

2. Wang, X.; Kiyokawa, H.; Dennewitz, M.B.; Costa, R.H. The Forkhead Box M1b Transcription Factor Is Essential for Hepatocyte DNA Replication and Mitosis during Mouse Liver Regeneration. Proc. Natl. Acad. Sci. USA 2002, 99, 16881-16886. [CrossRef]

3. Macedo, J.C.; Vaz, S.; Bakker, B.; Ribeiro, R.; Bakker, P.L.; Escandell, J.M.; Ferreira, M.G.; Medema, R.; Foijer, F.; Logarinho, E. FoxM1 Repression during Human Aging Leads to Mitotic Decline and Aneuploidy-Driven Full Senescence. Nat. Commun. 2018, 9, 1-17. [CrossRef] [PubMed]

4. Ustiyan, V.; Wang, I.-C.; Ren, X.; Zhang, Y.; Snyder, J.; Xu, Y.; Wert, S.E.; Lessard, J.L.; Kalin, T.V.; Kalinichenko, V.V. Forkhead Box M1 Transcriptional Factor Is Required for Smooth Muscle Cells during Embryonic Development of Blood Vessels and Esophagus. Dev. Biol. 2009, 336, 266-279. [CrossRef] 
5. Kalin, T.V.; Ustiyan, V.; Kalinichenko, V.V. Multiple Faces of FoxM1 Transcription Factor: Lessons from Transgenic Mouse Models. Cell Cycle 2011, 10, 396-405. [CrossRef]

6. Chang-Panesso, M.; Kadyrov, F.F.; Lalli, M.; Wu, H.; Ikeda, S.; Kefaloyianni, E.; Abdelmageed, M.M.; Herrlich, A.; Kobayashi, A.; Humphreys, B.D. FOXM1 Drives Proximal Tubule Proliferation during Repair from Acute Ischemic Kidney Injury. J. Clin. Investig. 2019, 129, 5501-5517. [CrossRef]

7. Korver, W.; Roose, J.; Clevers, H. The Winged-Helix Transcription Factor Trident Is Expressed in Cycling Cells. Nucleic Acids Res. 1997, 25, 1715-1719. [CrossRef]

8. Krupczak-Hollis, K.; Wang, X.; Kalinichenko, V.V.; Gusarova, G.A.; Wang, I.-C.; Dennewitz, M.B.; Yoder, H.M.; Kiyokawa, H.; Kaestner, K.H.; Costa, R.H. The Mouse Forkhead Box M1 Transcription Factor Is Essential for Hepatoblast Mitosis and De-velopment of Intrahepatic Bile Ducts and Vessels during Liver Morphogenesis. Dev. Biol. 2004, 276, 74-88. [CrossRef]

9. Ramakrishna, S.; Kim, I.-M.; Petrovic, V.; Malin, D.; Wang, I.-C.; Kalin, T.V.; Meliton, L.; Zhao, Y.-Y.; Ackerson, T.; Qin, Y.; et al. Myocardium Defects and Ventricular Hypoplasia in Mice Homozygous Null for TheForkhead Box M1 Transcription Factor. Dev. Dyn. 2007, 236, 1000-1013. [CrossRef]

10. Korver, W.; Schilham, M.W.; Moerer, P.; van den Hoff, M.J.; Dam, K.; Lamers, W.H.; Medema, R.H.; Clevers, H. Uncoupling of S Phase and Mitosis in Cardiomyocytes and Hepatocytes Lacking the Winged-Helix Transcription Factor Trident. Curr. Biol. 1998, 8, 1327-1330. [CrossRef]

11. Eckfeldt, C.E.; Mendenhall, E.M.; Flynn, C.M.; Wang, T.F.; Pickart, M.A.; Grindle, S.M.; Ekker, S.C.; Verfaillie, C.M. Functional Analysis of Human Hematopoietic Stem Cell Gene Expression Using Zebrafish. PLoS Biol. 2005, 3, e254. [CrossRef]

12. Sasagawa, S.; Nishimura, Y.; Hayakawa, Y.; Murakami, S.; Ashikawa, Y.; Yuge, M.; Okabe, S.; Kawaguchi, K.; Kawase, R.; Tanaka, T. E2F4 Promotes Neuronal Regeneration and Functional Recovery after Spinal Cord Injury in Zebrafish. Front. Pharmacol. 2016, 7, 119. [CrossRef] [PubMed]

13. Sadler, K.C.; Krahn, K.N.; Gaur, N.A.; Ukomadu, C. Liver Growth in the Embryo and during Liver Regeneration in Zebrafish Requires the Cell Cycle Regulator, Uhrf1. PNAS 2007, 104, 1570-1575. [CrossRef] [PubMed]

14. Marceau, A.H.; Brison, C.M.; Nerli, S.; Arsenault, H.E.; McShan, A.C.; Chen, E.; Lee, H.-W.; Benanti, J.A.; Sgourakis, N.G.; Rubin, S.M. An Order-to-Disorder Structural Switch Activates the FoxM1 Transcription Factor. eLife 2019, 8, e46131. [CrossRef]

15. Laoukili, J.; Alvarez, M.; Meijer, L.A.T.; Stahl, M.; Mohammed, S.; Kleij, L.; Heck, A.J.R.; Medema, R.H. Activation of FoxM1 during G2 Requires Cyclin A/Cdk-Dependent Relief of Autorepression by the FoxM1 N-Terminal Domain. Mol. Cell. Biol. 2008, 28, 3076-3087. [CrossRef]

16. Park, H.J.; Wang, Z.; Costa, R.H.; Tyner, A.; Lau, L.F.; Raychaudhuri, P. An N-Terminal Inhibitory Domain Modulates Activity of FoxM1 during Cell Cycle. Oncogene 2008, 27, 1696-1704. [CrossRef] [PubMed]

17. Major, M.L.; Lepe, R.; Costa, R.H. Forkhead Box M1B Transcriptional Activity Requires Binding of Cdk-Cyclin Complexes for Phosphorylation-Dependent Recruitment of P300/CBP Coactivators. Mol. Cell. Biol. 2004, 24, 2649-2661. [CrossRef] [PubMed]

18. Liao, G.B.; Li, X.Z.; Zeng, S.; Liu, C.; Yang, S.M.; Yang, L.; Hu, C.J.; Bai, J.Y. Regulation of the Master Regulator FOXM1 in Cancer. Cell Commun. Signal. 2018, 16, 1-15. [CrossRef]

19. Kim, Y.H.; Choi, M.H.; Kim, J.H.; Lim, I.K.; Park, T.J. C-Terminus-Deleted FoxM1 Is Expressed in Cancer Cell Lines and Induces Chromosome Instability. Carcinogenesis 2013, 34, 1907-1917. [CrossRef]

20. Zona, S.; Bella, L.; Burton, M.J.; Nestal de Moraes, G.; Lam, E.W.F. FOXM1: An Emerging Master Regulator of DNA Damage Response and Genotoxic Agent Resistance. Biochim. Biophys. Acta Gene Regul. Mech. 2014, 1839, 1316-1322. [CrossRef]

21. Black, M.; Arumugam, P.; Shukla, S.; Pradhan, A.; Ustiyan, V.; Milewski, D.; Kalinichenko, V.V.; Kalin, T.V. FOXM1 Nuclear Transcription Factor Translocates into Mitochondria and Inhibits Oxidative Phosphorylation. Mol. Biol. Cell 2020, 31, $1411-1424$. [CrossRef] [PubMed]

22. Rossi, G.; Messina, G. Comparative Myogenesis in Teleosts and Mammals. Cell. Mol. Life Sci. 2014, 71, 3081-3099. [CrossRef] [PubMed]

23. Jackson, H.E.; Ingham, P.W. Control of Muscle Fibre-Type Diversity during Embryonic Development: The Zebrafish Paradigm. Mech. Dev. 2013, 130, 447-457. [CrossRef]

24. Stickney, H.L.; Barresi, M.J.F.; Devoto, S.H. Somite Development in Zebrafish. Dev. Dyn. 2000, 219, 287-303. [CrossRef]

25. Keenan, S.R.; Currie, P.D. The Developmental Phases of Zebrafish Myogenesis. J. Dev. Biol. 2019, 7, 12. [CrossRef]

26. Nguyen, P.D.; Gurevich, D.B.; Sonntag, C.; Hersey, L.; Alaei, S.; Nim, H.T.; Siegel, A.; Hall, T.E.; Rossello, F.J.; Boyd, S.E.; et al. Muscle Stem Cells Undergo Extensive Clonal Drift during Tissue Growth via Meox1-Mediated Induction of G2 Cell-Cycle Arrest. Cell Stem Cell 2017, 21, 107-119.e6. [CrossRef]

27. Gurevich, D.B.; Nguyen, P.D.; Siegel, A.L.; Ehrlich, O.V.; Sonntag, C.; Phan, J.M.N.; Berger, S.; Ratnayake, D.; Hersey, L.; Berger, J.; et al. Asymmetric Division of Clonal Muscle Stem Cells Coordinates Muscle Regeneration in Vivo. Science 2016, 353, aad9969. [CrossRef]

28. Maves, L. Recent Advances Using Zebrafish Animal Models for Muscle Disease Drug Discovery. Expert Opin. Drug Discov. 2014, 9, 1033-1045. [CrossRef]

29. Hall, T.E.; Wood, A.J.; Ehrlich, O.; Li, M.; Sonntag, C.S.; Cole, N.J.; Huttner, I.G.; Sztal, T.E.; Currie, P.D. Cellular Rescue in a Zebrafish Model of Congenital Muscular Dystrophy Type 1A. npj Regen. Med. 2019, 4, 1-13. [CrossRef] [PubMed]

30. Berger, J.; Currie, P.D. Zebrafish Models Flex Their Muscles to Shed Light on Muscular Dystrophies. DMM Dis. Models Mech. 2012, 5, 726-732. [CrossRef] 
31. Knappe, S.; Zammit, P.S.; Knight, R.D. A Population of Pax7-Expressing Muscle Progenitor Cells Show Differential Responses to Muscle Injury Dependent on Developmental Stage and Injury Extent. Front. Aging Neurosci. 2015, 7, 161. [CrossRef] [PubMed]

32. Berberoglu, M.A.; Gallagher, T.L.; Morrow, Z.T.; Talbot, J.C.; Hromowyk, K.J.; Tenente, I.M.; Langenau, D.M.; Amacher, S.L. Satellite-like Cells Contribute to Pax7-Dependent Skeletal Muscle Repair in Adult Zebrafish. Dev. Biol. 2017, 424, 162-180. [CrossRef] [PubMed]

33. Chen, Z.; Bu, N.; Qiao, X.; Zuo, Z.; Shu, Y.; Liu, Z.; Qian, Z.; Chen, J.; Hou, Y. Forkhead Box M1 Transcriptionally Regulates the Expression of Long Noncoding RNAs Snhg8 and Gm26917 to Promote Proliferation and Survival of Muscle Satellite Cells. Stem Cells 2018, 36, 1097-1108. [CrossRef]

34. Chen, Z.; Li, L.; Xu, S.; Liu, Z.; Zhou, C.; Li, Z.; Liu, Y.; Wu, W.; Huang, Y.; Kuang, M.; et al. A Cdh1-FoxM1-Apc Axis Controls Muscle Development and Regeneration. Cell Death Dis. 2020, 11, 1-16. [CrossRef] [PubMed]

35. Blackburn, D.M.; Lazure, F.; Corchado, A.H.; Perkins, T.J.; Najafabadi, H.S.; Soleimani, V.D. High-Resolution Genome-Wide Expression Analysis of Single Myofibers Using Smart-Seq. J. Biol. Chem. 2019, 294, 20097-20108. [CrossRef] [PubMed]

36. Cornet, C.; di Donato, V.; Terriente, J. Combining Zebrafish and CRISPR/Cas9: Toward a More Efficient Drug Discovery Pipeline. Front. Pharmacol. 2018, 9, 703. [CrossRef] [PubMed]

37. Chang, H.H.Y.; Pannunzio, N.R.; Adachi, N.; Lieber, M.R. Non-Homologous DNA End Joining and Alternative Pathways to Double-Strand Break Repair. Nat. Rev. Mol. Cell Biol. 2017, 18, 495-506. [CrossRef]

38. Burger, A.; Lindsay, H.; Felker, A.; Hess, C.; Anders, C.; Chiavacci, E.; Zaugg, J.; Weber, L.M.; Catena, R.; Jinek, M.; et al. Maximizing Mutagenesis with Solubilized CRISPR-Cas9 Ribonucleoprotein Complexes. Development 2016, 143, $2025-2037$. [CrossRef]

39. Jao, L.E.; Wente, S.R.; Chen, W. Efficient Multiplex Biallelic Zebrafish Genome Editing Using a CRISPR Nuclease System. Proc. Natl. Acad. Sci. USA 2013, 110, 13904-13909. [CrossRef]

40. Ablain, J.; Durand, E.M.; Yang, S.; Zhou, Y.; Zon, L.I. A CRISPR/Cas9 Vector System for Tissue-Specific Gene Disruption in Zebrafish. Dev. Cell 2015, 32, 756-764. [CrossRef]

41. Ihry, R.J.; Worringer, K.A.; Salick, M.R.; Frias, E.; Ho, D.; Theriault, K.; Kommineni, S.; Chen, J.; Sondey, M.; Ye, C.; et al. P53 Inhibits CRISPR-Cas9 Engineering in Human Pluripotent Stem Cells. Nat. Med. 2018, 24, 939-946. [CrossRef] [PubMed]

42. Xu, S.; Kim, J.; Tang, Q.; Chen, Q.; Liu, J.; Xu, Y.; Fu, X. CAS9 Is a Genome Mutator by Directly Disrupting DNA-PK Dependent DNA Repair Pathway. Protein Cell 2020, 11, 352-365. [CrossRef]

43. Benchling [Biology Software]. Available online: https:// benchling.com (accessed on 1 April 2018).

44. Doench, J.G.; Fusi, N.; Sullender, M.; Hegde, M.; Vaimberg, E.W.; Donovan, K.F.; Smith, I.; Tothova, Z.; Wilen, C.; Orchard, R.; et al . Optimized SgRNA Design to Maximize Activity and Minimize Off-Target Effects of CRISPR-Cas9. Nat. Biotechnol. 2016, 34, 184-191. [CrossRef] [PubMed]

45. Hsu, P.D.; Scott, D.A.; Weinstein, J.A.; Ran, F.A.; Konermann, S.; Agarwala, V.; Li, Y.; Fine, E.J.; Wu, X.; Shalem, O.; et al. DNA Targeting Specificity of RNA-Guided Cas9 Nucleases. Nat. Biotechnol. 2013, 31, 827-832. [CrossRef] [PubMed]

46. Hwang, W.Y.; Fu, Y.; Reyon, D.; Maeder, M.L.; Tsai, S.Q.; Sander, J.D.; Peterson, R.T.; Yeh, J.R.J.; Joung, J.K. Efficient Genome Editing in Zebrafish Using a CRISPR-Cas System. Nat. Biotechnol. 2013, 31, 227-229. [CrossRef]

47. Bessa, J.; Gómez-Skarmeta, J.L. Making Reporter Gene Constructs to Analyze Cis-Regulatory Elements. Methods Mol. Biol. 2011, 772, 397-408. [CrossRef] [PubMed]

48. Brinkman, E.K.; Chen, T.; Amendola, M.; van Steensel, B. Easy Quantitative Assessment of Genome Editing by Sequence Trace Decomposition. Nucleic Acids Res. 2014, 42, e168. [CrossRef] [PubMed]

49. Schindelin, J.; Arganda-Carreras, I.; Frise, E.; Kaynig, V.; Longair, M.; Pietzsch, T.; Preibisch, S.; Rueden, C.; Saalfeld, S.; Schmid, B.; et al. Fiji: An Open-Source Platform for Biological-Image Analysis. Nat. Methods 2012, 9, 676-682. [CrossRef]

50. Sorrells, S.; Toruno, C.; Stewart, R.A.; Jette, C. Analysis of Apoptosis in Zebrafish Embryos by Whole-Mount Immunofluorescence to Detect Activated Caspase 3. J. Vis. Exp. 2013, 82, 51060. [CrossRef]

51. Kawakami, A.; Kimura-Kawakami, M.; Nomura, T.; Fujisawa, H. Distributions of PAX6 and PAX7 Proteins Suggest Their Involvement in Both Early and Late Phases of Chick Brain Development. Mech. Dev. 1997, 66, 119-130. [CrossRef]

52. Seger, C.; Hargrave, M.; Wang, X.; Chai, R.J.; Elworthy, S.; Ingham, P.W. Analysis of Pax7 Expressing Myogenic Cells in Zebrafish Muscle Development, Injury, and Models of Disease. Dev. Dyn. 2011, 240, 2440-2451. [CrossRef] [PubMed]

53. Moreno-Mateos, M.A.; Vejnar, C.E.; Beaudoin, J.D.; Fernandez, J.P.; Mis, E.K.; Khokha, M.K.; Giraldez, A.J. CRISPRscan: Designing Highly Efficient SgRNAs for CRISPR-Cas9 Targeting in Vivo. Nat. Methods 2015, 12, 982-988. [CrossRef]

54. Amrani, N.; Sachs, M.S.; Jacobson, A. Early Nonsense: MRNA Decay Solves a Translational Problem. Nat. Rev. Mol. Cell Biol. 2006, 7, 415-425. [CrossRef] [PubMed]

55. Lindeboom, R.G.H.; Supek, F.; Lehner, B. The Rules and Impact of Nonsense-Mediated MRNA Decay in Human Cancers. Nat. Genet. 2016, 48, 1112-1118. [CrossRef] [PubMed]

56. Wittkopp, N.; Huntzinger, E.; Weiler, C.; Saulière, J.; Schmidt, S.; Sonawane, M.; Izaurralde, E. Nonsense-Mediated MRNA Decay Effectors Are Essential for Zebrafish Embryonic Development and Survival. Mol. Cell. Biol. 2009, 29, 3517-3528. [CrossRef] [PubMed]

57. Nagy, E.; Maquat, L.E. A Rule for Termination-Codon Position within Intron-Containing Genes: When Nonsense Affects RNA Abundance. Trends Biochem. Sci. 1998, 23, 198-199. [CrossRef] 
58. Myatt, S.S.; Kongsema, M.; Man, C.W.Y.; Kelly, D.J.; Gomes, A.R.; Khongkow, P.; Karunarathna, U.; Zona, S.; Langer, J.K.; Dunsby, C.W.; et al. SUMOylation Inhibits FOXM1 Activity and Delays Mitotic Transition. Oncogene 2014, 33, 4316-4329. [CrossRef]

59. Lv, C.; Zhao, G.; Sun, X.; Wang, P.; Xie, N.; Luo, J.; Tong, T. Acetylation of FOXM1 Is Essential for Its Transactivation and Tumor Growth Stimulation. Oncotarget 2016, 7, 60366-60382. [CrossRef] [PubMed]

60. Zhu, X.; Xu, Y.; Yu, S.; Lu, L.; Ding, M.; Cheng, J.; Song, G.; Gao, X.; Yao, L.; Fan, D.; et al. An Efficient Genotyping Method for Genome-Modified Animals and Human Cells Generated with CRISPR/Cas9 System. Sci. Rep. 2014, 4, 6420. [CrossRef] [PubMed]

61. El-Brolosy, M.A.; Kontarakis, Z.; Rossi, A.; Kuenne, C.; Günther, S.; Fukuda, N.; Kikhi, K.; Boezio, G.L.M.; Takacs, C.M.; Lai, S.L.; et al. Genetic Compensation Triggered by Mutant MRNA Degradation. Nature 2019, 568, 193-197. [CrossRef]

62. Golson, M.L.; Kaestner, K.H. Fox Transcription Factors: From Development to Disease. Development 2016, 143, 4558-4570. [CrossRef]

63. Shimeld, S.M.; Degnan, B.; Luke, G.N. Evolutionary Genomics of the Fox Genes: Origin of Gene Families and the Ancestry of Gene Clusters. Genomics 2010, 95, 256-260. [CrossRef] [PubMed]

64. Van Overbeek, M.; Capurso, D.; Carter, M.M.; Thompson, M.S.; Frias, E.; Russ, C.; Reece-Hoyes, J.S.; Nye, C.; Gradia, S.; Vidal, B.; et al. DNA Repair Profiling Reveals Nonrandom Outcomes at Cas9-Mediated Breaks. Mol. Cell 2016, 63, 633-646. [CrossRef] [PubMed]

65. Taheri-Ghahfarokhi, A.; Taylor, B.J.M.; Nitsch, R.; Lundin, A.; Cavallo, A.L.; Madeyski-Bengtson, K.; Karlsson, F.; Clausen, M.; Hicks, R.; Mayr, L.M.; et al. Decoding Non-Random Mutational Signatures at Cas9 Targeted Sites. Nucleic Acids Res. 2018, 46, 8417-8434. [CrossRef]

66. Sacco, A.; Pajalunga, D.; Latella, L.; Siepi, F.; Rufini, A.; Crescenzi, M. Cell Cycle Reactivation in Skeletal Muscle and Other Terminally Differentiated Cells; Madame Curie Bioscience Database; Landes Bioscience: Austin, TX, USA, 2013.

67. Bessa, J.; Tena, J.J.; de La Calle-Mustienes, E.; Fernández-Miñán, A.; Naranjo, S.; Fernández, A.; Montoliu, L.; Akalin, A.; Lenhard, B.; Casares, F.; et al. Zebrafish Enhancer Detection (ZED) Vector: A New Tool to Facilitate Transgenesis and the Functional Analysis of Cis-Regulatory Regions in Zebrafish. Dev. Dyn. 2009, 238, 2409-2417. [CrossRef]

68. Uhlen, M.; Fagerberg, L.; Hallstrom, B.M.; Lindskog, C.; Oksvold, P.; Mardinoglu, A.; Sivertsson, A.; Kampf, C.; Sjostedt, E.; Asplund, A.; et al. Tissue-Based Map of the Human Proteome. Science 2015, 347, 1260419. [CrossRef] [PubMed]

69. Ju, B.; Chong, S.W.; He, J.; Wang, X.; Xu, Y.; Wan, H.; Tong, Y.; Yan, T.; Korzh, V.; Gong, Z. Recapitulation of Fast Skeletal Muscle Development in Zebrafish by Transgenic Expression of GFP under the Mylz2 Promoter. Dev. Dyn. 2003, 227, 14-26. [CrossRef] [PubMed]

70. Zhang, W.; Roy, S. The Zebrafish Fast Myosin Light Chain Mylpfa:H2B-GFP Transgene Is a Useful Tool for In Vivo Imaging of Myocyte Fusion in the Vertebrate Embryo. Gene Expr. Patterns 2016, 20, 106-110. [CrossRef] [PubMed]

71. Pourghadamyari, H.; Rezaei, M.; Ipakchi-Azimi, A.; Eisa-Beygi, S.; Basiri, M.; Tahamtani, Y.; Baharvand, H. Establishing a New Animal Model for Muscle Regeneration Studies. Mol. Biol. Res. Commun. 2019, 8, 171-179. [CrossRef]

72. Danial, N.N.; Korsmeyer, S.J. Cell Death: Critical Control Points. Cell 2004, 116, 205-219. [CrossRef]

73. Walsh, J.G.; Cullen, S.P.; Sheridan, C.; Lüthi, A.U.; Gerner, C.; Martin, S.J. Executioner Caspase-3 and Caspase-7 Are Functionally Distinct Proteases. Proc. Natl. Acad. Sci. USA 2008, 105, 12815-12819. [CrossRef] [PubMed]

74. Spead, O.; Verreet, T.; Donelson, C.J.; Poulain, F.E. Characterization of the Caspase Family in Zebrafish. PLoS ONE 2018, 13, e0197966. [CrossRef] [PubMed]

75. Zhao, X.; Zhao, L.; Tian, T.; Zhang, Y.; Tong, J.; Zheng, X.; Meng, A. Interruption of Cenph Causes Mitotic Failure and Embryonic Death, and Its Haploinsufficiency Suppresses Cancer in Zebrafish. J. Biol. Chem. 2010, 285, 27924-27934. [CrossRef] [PubMed]

76. Kratz, E.; Eimon, P.M.; Mukhyala, K.; Stern, H.; Zha, J.; Strasser, A.; Hart, R.; Ashkenazi, A. Functional Characterization of the Bcl-2 Gene Family in the Zebrafish. Cell Death Differ. 2006, 13, 1631-1640. [CrossRef]

77. Mathias, J.R.; Dodd, M.E.; Walters, K.B.; Yoo, S.K.; Ranheim, E.A.; Huttenlocher, A. Characterization of Zebrafish Larval Inflammatory Macrophages. Dev. Comp. Immunol. 2009, 33, 1212-1217. [CrossRef] [PubMed]

78. Elliott, M.R.; Ravichandran, K.S. The Dynamics of Apoptotic Cell Clearance. Dev. Cell 2016, 38, 147-160. [CrossRef] [PubMed]

79. Yang, S.; Li, S.; Li, X.J. Shortening the Half-Life of Cas9 Maintains Its Gene Editing Ability and Reduces Neuronal Toxicity. Cell Rep. 2018, 25, 2653-2659.e3. [CrossRef]

80. Pedersen, B.K.; Febbraio, M.A. Muscle as an Endocrine Organ: Focus on Muscle-Derived Interleukin-6. Physiol. Rev. 2008, 88, 1379-1406. [CrossRef]

81. Pedersen, B.K. Muscle as a Secretory Organ. In Comprehensive Physiology; John Wiley \& Sons, Inc.: Hoboken, NJ, USA, 2013; Volume 3, pp. 1337-1362.

82. Pillon, N.J.; Bilan, P.J.; Fink, L.N.; Klip, A. Cross-Talk between Skeletal Muscle and Immune Cells: Muscle-Derived Mediators and Metabolic Implications. Am. J. Physiol. Endocrinol. Metab. 2013, 304, 453-465. [CrossRef]

83. Palstra, A.P.; Rovira, M.; Rizo-Roca, D.; Torrella, J.R.; Spaink, H.P.; Planas, J.V. Swimming-Induced Exercise Promotes Hypertrophy and Vascularization of Fast Skeletal Muscle Fibres and Activation of Myogenic and Angiogenic Transcriptional Programs in Adult Zebrafish. BMC Genom. 2014, 15, 1136. [CrossRef]

84. Rovira, M.; Arrey, G.; Planas, J.V. Exercise-Induced Hypertrophic and Oxidative Signaling Pathways and Myokine Expression in Fast Muscle of Adult Zebrafish. Front. Physiol. 2017, 8, 1063. [CrossRef] [PubMed] 
85. Pipalia, T.G.; Koth, J.; Roy, S.D.; Hammond, C.L.; Kawakami, K.; Hughes, S.M. Cellular Dynamics of Regeneration Reveals Role of Two Distinct Pax7 Stem Cell Populations in Larval Zebrafish Muscle Repair. DMM Dis. Models Mech. 2016, 9, 671-684. [CrossRef]

86. Roy, S.D.; Williams, V.C.; Pipalia, T.G.; Li, K.; Hammond, C.L.; Knappe, S.; Knight, R.D.; Hughes, S.M. Myotome Adaptability Confers Developmental Robustness to Somitic Myogenesis in Response to Fibre Number Alteration. Dev. Biol. 2017, 431, 321-335. [CrossRef] [PubMed]

87. Balli, D.; Ustiyan, V.; Zhang, Y.; Wang, I.-C.; Masino, A.J.; Ren, X.; Whitsett, J.A.; Kalinichenko, V.V.; Kalin, T.V. Foxm1 Transcription Factor Is Required for Lung Fibrosis and Epithelial-to-Mesenchymal Transition. EMBO J. 2013, 32, 231-244. [CrossRef] [PubMed]

88. Zeng, R.-M.; Lu, X.-H.; Lin, J.; Hu, J.; Rong, Z.-J.; Xu, W.-C.; Liu, Z.-W.; Zeng, W.-T. Knockdown of FOXM1 Attenuates Inflammatory Response in Human Osteoarthritis Chondrocytes. Int. Immunopharmacol. 2019, 68, 74-80. [CrossRef]

89. Toth, K.G.; McKay, B.R.; de Lisio, M.; Little, J.P.; Tarnopolsky, M.A.; Parise, G. IL-6 Induced STAT3 Signalling Is Associated with the Proliferation of Human Muscle Satellite Cells Following Acute Muscle Damage. PLoS ONE 2011, 6, e17392. [CrossRef]

90. Steyn, P.J.; Dzobo, K.; Smith, R.I.; Myburgh, K.H. Interleukin-6 Induces Myogenic Differentiation via JAK2-STAT3 Signaling in Mouse C2C12 Myoblast Cell Line and Primary Human Myoblasts. Int. J. Mol. Sci. 2019, 20, 5273. [CrossRef]

91. Spangenburg, E.E.; Booth, F.W. Multiple Signaling Pathways Mediate LIF-Induced Skeletal Muscle Satellite Cell Proliferation. Am. J. Physiol. Cell Physiol. 2002, 283, C204-C211. [CrossRef]

92. Miller, K.J.; Thaloor, D.; Matteson, S.; Pavlath, G.K. Hepatocyte Growth Factor Affects Satellite Cell Activation and Differen-tiation in Regenerating Skeletal Muscle. Am. J. Physiol. Cell Physiol. 2000, 278, C174-C181. [CrossRef]

93. Wang, H.; Noulet, F.; Edom-Vovard, F.; le Grand, F.; Duprez, D. Bmp Signaling at the Tips of Skeletal Muscles Regulates the Number of Fetal Muscle Progenitors and Satellite Cells during Development. Dev. Cell 2010, 18, 643-654. [CrossRef]

94. Ono, Y.; Calhabeu, F.; Morgan, J.E.; Katagiri, T.; Amthor, H.; Zammit, P.S. BMP Signalling Permits Population Expansion by Preventing Premature Myogenic Differentiation in Muscle Satellite Cells. Cell Death Differ. 2011, 18, 222-234. [CrossRef] [PubMed]

95. Stantzou, A.; Schirwis, E.; Swist, S.; Alonso-Martin, S.; Polydorou, I.; Zarrouki, F.; Mouisel, E.; Beley, C.; Julien, A.; le Grand, F.; et al. BMP Signaling Regulates Satellite Cell-Dependent Postnatal Muscle Growth. Development 2017, 144, $2737-2747$. [CrossRef]

96. Pawlikowski, B.; Vogler, T.O.; Gadek, K.; Olwin, B.B. Regulation of Skeletal Muscle Stem Cells by Fibroblast Growth Factors. Dev. Dyn. 2017, 246, 359-367. [CrossRef] [PubMed]

97. Sun, L.; Ren, X.; Wang, I.C.; Pradhan, A.; Zhang, Y.; Flood, H.M.; Han, B.; Whitsett, J.A.; Kalin, T.V.; Kalinichenko, V.V. The FOXM1 Inhibitor RCM-1 Suppresses Goblet Cell Metaplasia and Prevents IL-13 and STAT6 Signaling in Allergen-Exposed Mice. Sci. Signal. 2017, 10, eaai8583. [CrossRef] [PubMed]

98. Sawaya, A.P.; Stone, R.C.; Brooks, S.R.; Pastar, I.; Jozic, I.; Hasneen, K.; O’Neill, K.; Mehdizadeh, S.; Head, C.R.; Strbo, N.; et al. Deregulated Immune Cell Recruitment Orchestrated by FOXM1 Impairs Human Diabetic Wound Healing. Nat. Commun. 2020, 11, 1-14. [CrossRef] 